\title{
PENGGUNAAN PROBIOTIK PADA PAKAN IKAN BAWAL BINTANG (Trachinotus blochii)
}

\section{THE USE OF PROBIOTICS ON STAR POMFRET FISH (Trachinotus blochii) DIET}

\author{
Hamdani $^{\left.1^{*}\right)}$, Saptono Waspodo ${ }^{1)}$, Ayu Adhita Damayanti ${ }^{1)}$ \\ ${ }^{1)}$ Fakultas Pertanian, Program Studi Budidaya Perairan, Universitas Mataram \\ Jl. Pendididkan No. 37 Mataram, NTB.
}

\begin{abstract}
Abstrak
Penelitian ini bertujuan untuk mengetahui pengaruh pemberian probiotik dengan dosis yang berbeda pada pakan terhadap pertumbuhan benih ikan bawal bintang (Trachinotus blochii). Penelitian ini dilaksanakan selama 30 hari yaitu pada tanggal 29 Januari sampai tanggal 2 Maret, 2018 yang bertempat di Balai Perikanan Budidaya Laut (BPBL) Lombok. Rancangan yang digunakan dalam penelitian ini yaitu Rancangan Acak Lengkap (RAL) yang terdiri dari 4 perlakuan dan 4 ulangan yaitu: P1 pemberian probiotik $25 \mathrm{ml} / \mathrm{kg}$ pakan sebagai kontrol, P2 pemberian probiotik $30 \mathrm{ml} / \mathrm{kg}$ pakan, P3 pemberian probiotik $35 \mathrm{ml} / \mathrm{kg}$ pakan, dan $\mathrm{P} 4$ pemberian probiotik $40 \mathrm{ml} / \mathrm{kg}$ pakan. Data yang diperoleh di analisa menggunakan analysis of variance (ANOVA) pada taraf yang nyata 5\% dengan menggunakan program SPSS dan dilakukan uji lanjut Tukey dengan taraf nyata 5\% untuk mengetahui perlakuan yang terbaik. Parameter yang diamati yaitu pertumbuhan berat mutlak, panjang mutlak, tingkat kelangsungan hidup dan kualitas air. Hasil penelitian menunjukan pemberian probiotik memberikan pengaruh terhadap pertumbuhan dan kelangsungan hidup benih ikan bawal bintang (Trachinotus blochii). Dosis probiotik terbaik yaitu $40 \mathrm{ml} / \mathrm{kg}$ pakan yang dapat memberikan pengaruh optimal terhadap pertumbuhan benih ikan bawal bintang (Trachinotus blochii).
\end{abstract}

Kata kunci : bawal bintang, probiotik, pertumbuhan, kelangsungan hidup.

\begin{abstract}
The research aimed to analyze the effect of adding different dose of probiotics on the growth of star pomfret fish (Trachinotus blochii). This research was conducted for 30 days from January $29^{\text {th }}$ to March $2{ }^{\text {nd }}$ 2018, at Balai Perikanan Budidaya Laut (BPBL) Lombok, West Nusa Tenggara Province. The design used in this study were Complete Random Design (CRD) consisting of 4 treatments and 4 replications, namely: P1 administration of probiotics $25 \mathrm{ml} / \mathrm{kg}$ of feed as control, $\mathrm{P} 2$ administration of probiotics $30 \mathrm{ml} / \mathrm{kg}$ of feed, P3 administration of probiotics $35 \mathrm{ml} / \mathrm{kg}$ feed, and P4 giving probiotics $40 \mathrm{ml} / \mathrm{kg}$ of feed. The data obtained were analyzed using analysis of variance (ANOVA) at a real level of 5\% using the SPSS program and Tukey's advanced test was carried out with a 5\% significance level to find out the best treatment. The parameters observed were absolute weight growth, absolute length, survival rate and water quality. The results showed that the effect of addition of probiotics significantly effected to the growth and survival of star pomfret seeds (Trachinotus blochii). The probiotics supplementation of $40 \mathrm{ml} / \mathrm{kg}$ feed gave best growth of star pomfret seeds (Trachinotus blochii)
\end{abstract}

Keywords : star pomfret fish, probiotics, growth, survival.

\section{Pendahuluan}

Salah satu komoditas baru ikan budidaya di Indonesia adalah ikan bawal bintang (Trachinotus blochii) yang memiliki potensi besar untuk dikembangkan dan pasar yang

*email korespondensi : hd80819@gmail.com cukup menjanjikan, baik dalam maupun luar negeri. Pada tahun 2007, pembenihan ikan bawal bintang sudah berhasil dilakukan di Balai Perikanan Budidaya Laut Batam untuk pertama kali di Indonesia (Abdulgani, 2013). Selama ini budidaya ikan bawal bintang di 
Indonesia, terutama tahap pembesarannya masih dilakukan di laut yaitu dengan sistem KJA (Keramba Jaring Apung).

Salah satu faktor penunjang keberhasilan dalam melakukan kegiatan budidaya pada tahap pembesaran adalah pakan. Pakan merupakan salah satu unsur penting dalam kegiatan budidaya yang menunjang pertumbuhan dan kelangsungan hidup pada ikan. Pakan pada kegiatan budidaya umumnya adalah pakan komersial yang menghabiskan sekitar $60-70 \%$ dari total biaya produksi yang dikeluarkan. Untuk itu, upaya meningkatkan efisiensi pakan senantiasa dilakukan oleh para pembudidaya, salah satu langkah yang ditempuh adalah dengan menambahkan probiotik dalam pakan. Menurut Mitra (2013) dalam Anugraheni (2016), salah satu probiotik yang dikenal dipasaran adalah EM4 (Effective Microorganism) diketahui dapat di gunakan sebgai bahan campuran pakan dan juga dapat menigkatkan kadar protein dalam pakan diduga bakteri ini mampu berperan aktif dalam membantu proses pertumbuhan.

\section{Metode Penelitian}

Penelitian ini dilaksanakan selama 30 hari yaitu pada tanggal 29 Januari sampai tanggal 2 Maret 2018, yang bertempat di Balai Perikanan Budidaya Laut (BPBL) Lombok, Direktorat Jendral Perikanan Budidaya, Kementrian Kelautan dan Perikanan Stasiun Sekotong, Kabupaten Lombok Barat, Provinsi Nusa Tenggara Barat.

\section{Metode dan rancangan percobaan}

Penelitian ini menggunakan metode eksperimental. Rancangan percobaan yang digunakan dalam penelitian ini adalah Rancangan Acak Lengkap (RAL) yang terdiri dari 4 perlakuan dan 4 kali ulangan sehingga diperoleh 16 unit percobaan. Perlakuan yang diujikan adalah pemberian probiotik ke pakan yaitu: $\mathrm{P} 1=$ Pemberian probiotik $25 \mathrm{ml} / \mathrm{kg}$ pakan sebagai media konrol, P2 = Pemberian probiotik $30 \mathrm{ml} / \mathrm{kg}$ pakan, $\mathrm{P} 3=$ Pemberian probiotik $35 \mathrm{ml} / \mathrm{kg}$ pakan, $\mathrm{P} 4=$ Pemberian probiotik $40 \mathrm{ml} / \mathrm{kg}$ pakan.

\section{Persiapan wadah dan ikan uji}

Wadah yang digunakan untuk pemeliharaan berupa bak kontainer sebanyak 16 unit dengan volume air 40 liter yang diisi dengan air laut sebayak 30 liter dengan padat tebar untuk masing masing wadah berisi 15 ekor ikan bawal bintang dalam satu wadah.

\section{Persiapan pakan uji}

Pakan yang digunakan pada penelitian ini adalah pakan komersial berupa pellet Merubeni Nisshin Feed, Made In Japan. Probiotik yang digunakan dalam penelitian ini adalah jenis EM4. Pemberian probiotik dilakukan dengan metode penyemprotan pada setiap kali pemberian pakan pada masingmasing perlakuan dan ulangan. Frekuensi pemberian pakan mengacu pada penelitianya (Prellia dkk., 2016), tiga kali sehari yaitu pada pukul 08.00 WITA, 12.00 WITA, 16.00 WITA. Jumlah pakan yang diberikan per hari sebanyak 5\% dari total berat ikan. Jadi dalam satu hari pakan diberikan sebanyak $15 \%$ pada masing-masing perlakuan.

\section{Analisis data}

Parameter yang diuji dengan analisis statistik adalah pertumbuhan berat mutlak dengan rumus $(\mathrm{W}=\mathrm{Wt}-\mathrm{Wo})$. Dimana $\mathrm{W}=$ Pertumbuhan mutlak rata- rata $(\mathrm{g}), \mathrm{Wt}=$ Berat mutlak individu rata-rata selama waktu pemeliharaan $(\mathrm{g})$, Wo $=$ Berat mutlak individu rata-rata awal pemeliharaan (g). Selanjutnnya pertumbahan panjang mutlak dengan rumus $(\mathrm{L}=\mathrm{Lt}-\mathrm{Lo})$. Dimana : $\mathrm{L}=$ Pertumbuhan panjang mutlak individu rata- rata $(\mathrm{cm}), \mathrm{Lt}=$ Panjang mutlak individu rata-rata selama waktu pemeliharaan $(\mathrm{cm}), \quad \mathrm{Lo}=$ Panjang mutlak individu rata-rata awal pemeliharaan (cm) dan tingkat kelangsungan hidup (SR) : $\mathrm{SR}=(\mathrm{Nt} / \mathrm{No}) \times 100 \%$. Keterangan: $\mathrm{SR}=$ Kelangsungan hidup ikan (\%), Nt $=$ Jumlah ikan yang hidup pada akhir pengamatan (ekor), $\quad \mathrm{N} 0=$ Jumlah ikan pada awal pengamatan (ekor) (Ardhanisya, 2017).

Apabila hasil analisis statistik menunjukan pengaruh yang berbeda nyata, dilanjutkan dengan uji lanjut tukey pada taraf yang nyata $5 \%$ untuk mengetahui perlakuan yang terbaik.

\section{Kualitas air}

Parameter kualitas air diukur setiap 1 minggu sekali, adapun parameter kualitas air yang diukur yaitu: suhu, salinitas $\mathrm{pH}, \mathrm{DO}$, diukur pada pukul 08.00 dan 12.00 . Pengukuran suhu dengan menggunakan thermometer, pengukuran $\mathrm{pH}$ dengan menggunakan $\mathrm{pH}$ meter digital, pengukuran salinitas dengan menggunakan refraktometer 
dan pengukuran DO dengan menggunakan DO meter.

\section{Hasil}

\section{Pertumbuhan Berat Mutlak}

Dari hasil pengamatan pertumbuhan berat mutlak ikan bawal bintang selama 30 hari pemeliharaan pada (Gambar 1). Dimana nilai tertinggi pada perlakuan P4 sebanyak 4,76 gram, kemudian perlakuan P3 sebanyak 4,04 gram, kemudian P2 sebanyak 3,63 gram, dan nilai terendah pada perlakuan P1 sebanyak 3,58 gram.

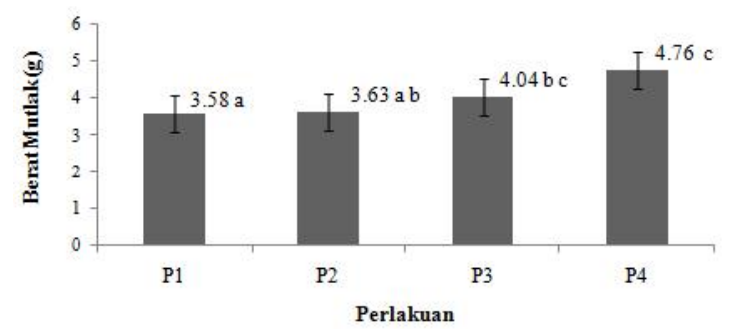

Gambar 1. Grafik pertumbuhan berat mutlak benih Ikan Bawal Bintang (Trachinotus blochii)

\section{Pertumbuhan Panjang Mutlak}

Dari hasil pengamatan pertumbuhan panjang mutlak ikan bawal bintang selama 30 hari pemeliharaan pada (Gambar 2). Dimana nilai tertinggi pada perlakuan P4 sebanyak 2,78 cm, kemudian perlakuan P3 sebanyak 2,55 cm, kemudian P2 sebanyak 2,3 cm, dan nilai terendah pada perlakuan P1 sebanyak 2,28 gram.

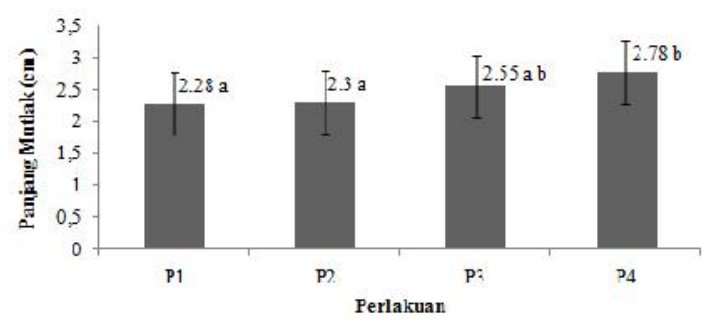

Gambar 2. Grafik pertumbuhan panjang mutlak benih Ikan Bawal Bintang (Trachinotus blochii)

\section{Kelangsungan Hidup (SR)}

Dari hasil pengamatan tingkat kelangsungan hidup benih ikan bawal bintang selama 30 hari pemeliharaan pada (Gambar 3). Dimana nilai tertinggi pada perlakuan P1 sebanyak 98,25\% kemudian P2 sebanyak 94,75\% kemudian P3 sebesar 84,75\% dan P4 sebesar $84,75 \%$.

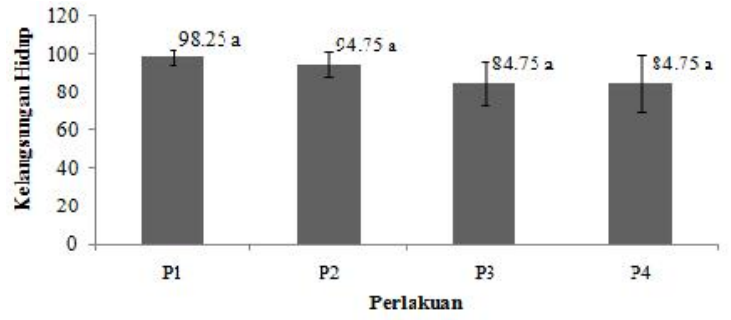

Gambar 3. Grafik kelangsungan hidup benih Ikan Bawal Bintang (Trachinotus blochii)

\section{Kualitas Air}

Dari hasil pengamatan kualitas air ikan bawal bintang selama 30 hari melakuakan kegiatan pemeliharaan didapatkan hasil pengukuran dengan rata-rata $\mathrm{pH} 7,8$, Do 6,0 $\mathrm{mg} / \mathrm{L}$, Suhu $27 \mathrm{C}^{\circ}$ dan salinitas $36 \mathrm{ppt}$.

\section{Pembahasan}

\section{Pertumbuhan Berat Mutlak dan Panjang Mutlak Benih Ikan Bawal Bintang}

Pertumbuhan mutlak adalah pertambahan berat dan panjang pada awal dan akhir pemeliharaan. Pertumbuhan berat mutlak dan panjang mutlak ikan bawal bintang disajikan pada (Gambar 1 dan Gambar 2), itu menunjukkan bahwa pada perlakuan P4 dengan dosis probiotik $40 \mathrm{ml} / \mathrm{kg}$ pakan memberikan hasil pertumbuhan berat mutlak dan panjang mutlak tertinggi jika dibandingkan dengan perlakuan P3 dengan dosis probiotik sebanyak $35 \mathrm{ml} / \mathrm{kg}$, kemudian $\mathrm{P} 2$ dengan dosis sebanyak $30 \mathrm{ml} / \mathrm{kg}$ pakan dan P1 dengan dosis probiotik sebanyak $25 \mathrm{ml} / \mathrm{kg}$ pakan. Hasil ini menunjukan semakin banyak dosis probiotik maka pertumbuhan berat dan panjang benih ikan bawal bintang semakin meningkat. Menurut Hendrianto \& Zaeni (2009), pakan yang diberi tambahan probiotik EM4 lebih baik pertumbuhan bobot dan panjangnya dibanding ikan yang hanya diberi pakan pellet.

\section{Kelangsungan Hidup (SR) Benih Ikan Bawal Bintang}

Kelangsungan hidup merupakan persentase organisme yang mampu bertahan hidup selama waktu pemeliharan. Dilihat dari grafik pada (Gambar 3). Menunjukkan bahwa tingkat kelangsungan hidup ikan bawal bintang rata-rata dari semua perlakuan hampir mendekati $100 \%$ itu berarti benih ikan bawal bintang sudah mampu beradaptasi dengan 
lingkungannya. Tingkat kelangsungan hidup juga dipengaruhi oleh laju pertumbuhan, tigkat seteres, kualitas air tempat pemeliharaan. Menurut Irwan (2014) dalam Hermawan (2007), tingkat kelangsungan hidup juga dipengaruhi oleh beberapa faktor seperti steres, kualitas air tempat pemeliharaan, organism pengotor, dan keberadaan predator serta kompetitor.

\section{Kualitas Air Benih Ikan Bawal Bintang}

Hasil pengukuran kualitas air selama 30 hari pemeliharaan ikan bawal bintang didapatkan rata-rata yaitu untuk $\mathrm{pH}$ sebanyak 7,8 , suhu sebanyak $27^{\circ} \mathrm{C}$, DO sebanyak 6,0 $\mathrm{mg} / \mathrm{L}$ dan salinitas sebanyak $36 \mathrm{ppt}$. Menurut Adekayasa (2015), kisaran Ph, Suhu, Do dan salinitas yang optimal berturut turut yaitu, $\mathrm{pH}$ 6,8-8,4, suhu $27^{\circ} \mathrm{C}-32^{\circ} \mathrm{C}$, DO 5,0-7,0 mg/L, salinitas $32 \mathrm{ppt}-42 \mathrm{ppt}$. Dari hasil pengukuran kualitas air maka dapat dikatakan bahwa kualitas air ikan bawal bintang masih dalam keadaan normal untuk digunakan dalam kegiatan budidaya.

\section{Kesimpulan}

Dari hasil penelitian ini dapat disimpulkan bahwa, pemberian probiotik pada pakan memberikan pengaruh signifikan terhadap pertumbuhan ikan bawal bintang dan dosis probiotik terbaik yaitu $40 \mathrm{ml} / \mathrm{kg}$ pakan, yang dapat memberikan pengaruh optimal terhadap pertumbuhan ikan bawal bintang.

\section{Ucapan Terima Kasih}

Ucapan terima kasih disampaikan kepada Balai Perikaanan Budidaya Laut (BPBL) Lombok, Direktorat Jendral Perikanan Budidaya, Kementrian Kelautan dan Perikanan Stasiun Sekotong, Kabupaten Lombok Barat, Provinsi Nusa Tenggara Barat yang telah meberikan izin kepada penulis untuk melakuakan kegiatan penelitian.

\section{Daftar Pustaka}

Anugraheni, R. (2016). Pengaruh Penambahan Probiotik EM4 Pada Pakan Terhadap Pertumbuhan Ikan Nila Merah. (Skripsi, tidak dipublikasikan.) Program Studi Pendidikan Biologi, Jurusan Pendidikan dan Ilmu Pengetahuan Alam, Fakultas Keguruan dan Ilmu Pendidikan, Universitas Sanata Dharma, Yogyakarta.

Abdulgani. (2013). Survival Rate Ikan Bawal Bintang (Trachinotusblochii) dalam Media Pemeliharaan Menggunakan Rekayasa Salinita. Jurnal Sains Dan Seni ITS. 1 (1).

Adekayasa, Y. ( 2015). Pengaruh Frekuensi Pemberian Pakan Terhadap Pertumbuhan Dan Tingkat Kelangsungan Hidup Benih Ikan Bawal Bintang (Trachinotus blochii). (Skripsi, tidak dipublikasikan.) Progaram Studi Budidaya Perairan, Fakultas Ilmu Kelautan Dan Perikanan, Univesitas Negeri Mataram.

Ardhanisya, Q. (2017). Tingkat Pertumbuhan Benih Bawal Bintang (Trachinotus blonchii) Dengan Manajemen Pakan yang Berbeda. (Skripsi tidak dipublikasikan.). Progaram Studi Budidaya Perairan, Fakultas Ilmu Kelautan Dan Perikanan, Univesitas Negeri Mataram.

Hermawan. (2007). Pengaruh Pemberian Probiotik Melalui Pakan Terhadap Pertumbuhan dan Kelangsungan Hidup Udang Windu (Peneaeus monodon). (Skripsi, tidak dipublikasikan.) Institut Pertanian Bogor.

Hendrianto, \& Zaeni, A. (2009). Aplikasi Imuno-probiotik dalam Pendederan Kerapu Macan (Ephinephelus fuscoguttatus) dan Dampaknya Terhadap Imunitas dan Tingkat

Kelulushidupan. Laporan penelitian Balai Budidaya Laut Batam.

Prellia, D., Usman, M. T., Rusliadi. (2016). The Effect of Probiotic Addition with Different Dose in Feed to the Growth of Fish Silver Pompano (Trachinotus blochii, Lacepede). Jurnal Online Mahasiswa (JOM) Bidang Perikanan dan Ilmu Kelautan, 3 (2), 1-9. Retrieved from: http:/jom.unri.ac.id/index.php/JOMFAPER IKA/article/view/10804/ 10459 